\title{
BOEKBESPREKING: YOGYA SILVER, RENEWAL OF JAVANESE HANDICRAFT
}

'Yogya zilver! Alleen de geur al kan ik me zo voor de geest halen, het stinkt door het lage gehalte zilver,' aldus een taxateur toen Yogya-zilver ter sprake kwam.

Zilver met typische Indonesische vormentaal dat vervaardigd is in het interbellum, is in grote hoeveelheden in Nederland terechtgekomen als souvenir voor familie of als aandenken aan de eigen Indische tijd. Hoewel hiervoor nieuwe belangstelling is ontstaan, wordt het door velen nog steeds verguisd vanwege het lage zilvergehalte of het gebrek aan artisticiteit van de zilversmeden. Maar vooral vanwege het feit dat het vandaag de dag nog steeds splinternieuw gekocht kan worden in Indonesië. Dit zilver zomaar af te doen als 'toeristengoed' zou echter geen recht doen aan het onderwerp. Het ontstaan van de herkenbare vormentaal in het ornament is bijzonder interessant, en goed kunsthistorisch en historisch onderzoek stelt ons in staat om voorwerpen te herkennen die kwalitatief en artistiek boven de massa uitstijgen.

Het handzame boekje Yogya Silver, Renewal of a Javanese Handicraft van Pienke Kal dat vorig jaar verscheen bij de gelijknamige tentoonstelling over dit onderwerp in het Tropenmuseum, is de eerste uiting van de nieuwe belangstelling en de eerste stap naar uitgebreider onderzoek naar het edelmetaal dat ontstond aan het einde van het koloniale tijdperk in Nederlands-Indië. Het is moeilijk om een goed overzicht te geven van een onderwerp waar nog nagenoeg geen onderzoek naar gedaan is. Het Yogyazilver wordt slechts zelden serieus verzameld, waardoor er nauwelijks gebruik gemaakt kan worden van kennis van verzamelaars. Bovendien is er - anders dan men misschien verwacht - betrekkelijk weinig informatie voorhanden over het sociale en culturele leven in Nederlands-Indië, waardoor ook de context - kopers, de functie van de objecten - geen gemakkelijke ingang biedt tot het onderwerp. Een zeldzaam en boeiend aanknopingspunt, dat de kern vormt voor deze publicatie en tentoonstelling, leverde de ontmoeting met een nazaat van Mary Agnes van Gesseler Verschuir die een rol speelde bij de ontwikkeling van Yogya-zilver. Zij beschikte over een grote groep voorwerpen, waarvan vaststaat in welke periode ze zijn vervaardigd.

Het boek is opgebouwd rond bovenstaande verzameling en gaat uitvoerig in op de rol die Van Gesseler Verschuir speelde in de bloeiperiode van het Yogya-zilver. Tegelijkertijd (en dat werkt enigszins verwarrend) probeert de auteur een beeld te geven van de gehéle edelmetaalnijverheid in Yogyakarta, doorlopend tot het heden. De aandacht voor Yogya-zilver na de onafhankelijkheid van Indonesië in 1945 ligt voor de hand, maar dat geldt niet voor het opnemen van één moderne ontwerpster van sieraden als afsluiting van het hoofdstuk over modern zilver in Indonesiè. ook in de tentoonstelling waren 13AM 
Afbeelding 1

Doos, $12,9 \times 8 \mathrm{~cm}$, 1930-1932, collectie Van Gesseler Verschuir

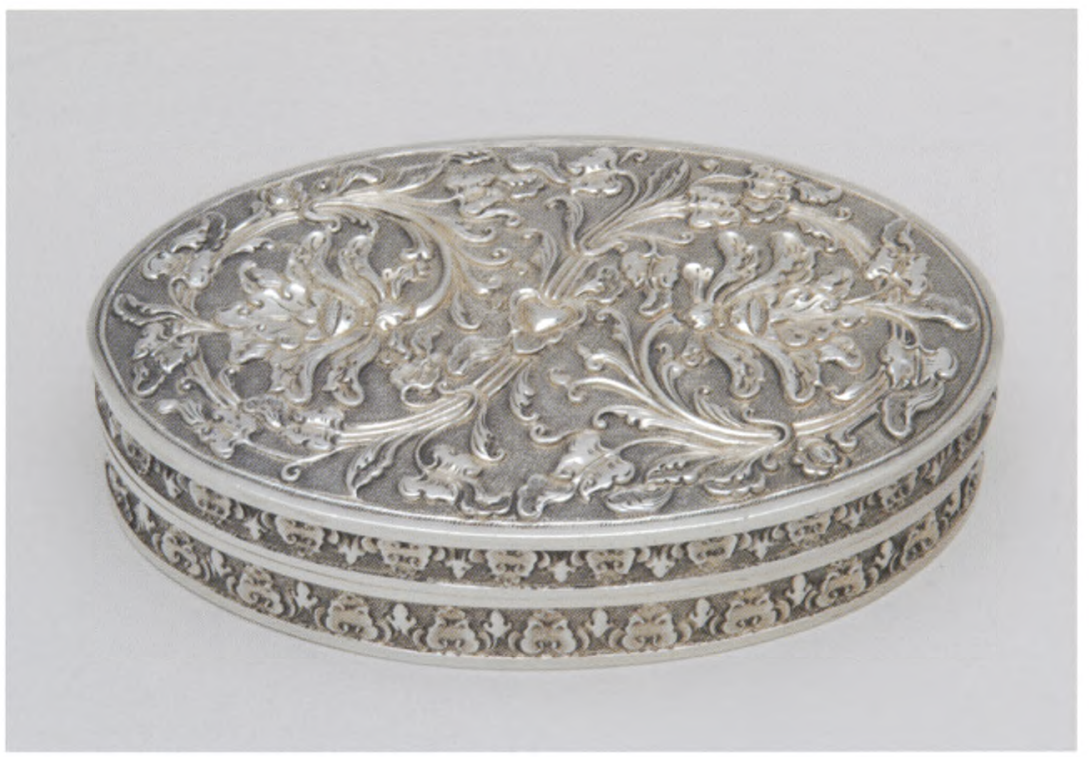

de sieraden van deze ontwerpster een vreemde eend in de bijt, temeer omdat tussen haar ontwerpen en het Yogya-zilver geen verband gelegd kan worden. De opbouw van de publicatie is helder: op een historische uiteenzetting volgt een catalogusgedeelte en daarnaast behandelen aparte hoofdstukken de technieken, zilvergehaltes en motieven en decoraties. Dit laatste hoofdstuk vormt het meest interessante deel van het boek. Het biedt de lezer de mogelijkheid om verschillende motieven op het zilver te herkennen en het betrekt daarbij steeds de voorwerpen in het catalogusgedeelte waardoor de voorwerpen meer worden dan een willekeurige klomp zilver. Dat er bij sommige voorwerpen bijna één op één is gekopieerd van stenen reliëfs van hindoe-javaanse monumenten wordt ondubbelzinnig geïllustreerd aan de hand van foto's.

Kal stipt in dit hoofdstuk ook de invloeden aan van Europese stijlen in Nederlands-Indië. Deze zijn zeker aanwijsbaar in batikpatronen en meubelen voor de Europese markt in Nederlands-Indië. Volgens haar zou er daarnaast al in de eerste jaren van de $20^{\mathrm{e}}$ eeuw sprake zijn van de toepassing van Indonesische siermotieven in de Nederlandse Nieuwe Kunst. Deze Indonesische invloed is echter maar klein geweest. In Nederland bestond - vooral bij kunstenaars en vormgevers - wel degelijk interesse in de hindoe-javaanse periode en in Indonesische etnografica, maar de Indonesische motieven en ornamenten stonden nog te ver af van het gangbare Nederlandse vormgevoel. De interesse heeft daardoor aanvankelijk niet geleid tot een grote invloed van de Indonesische ornamentiek; pas in de periode na 1915 zijn in de toegepaste kunst en architectuur meer Indonesische invloeden aanwijsbaar. Bijzonder aan het Yogya-zilver is dat het in Nederlands-Indië in de mode raakte terwijl het sterk afweek van hetgeen in Europa in de mode was.

Het succes is eigenlijk nog frappanter als men bedenkt dat de Nederlandse zilverfabriek Van Kempen en Begeer vijf grote filialen had in NederlandsIndië waar men veel courante en modieuze zilveren voorwerpen kon kopen. In het boek worden de Nederlandse initiatieven beschreven om de Javaanse zilverbewerking voor de ondergang te behoeden. De opdrachten van oph $^{\text {Bri }} \mathbf{e}_{\text {ee }}$ access 


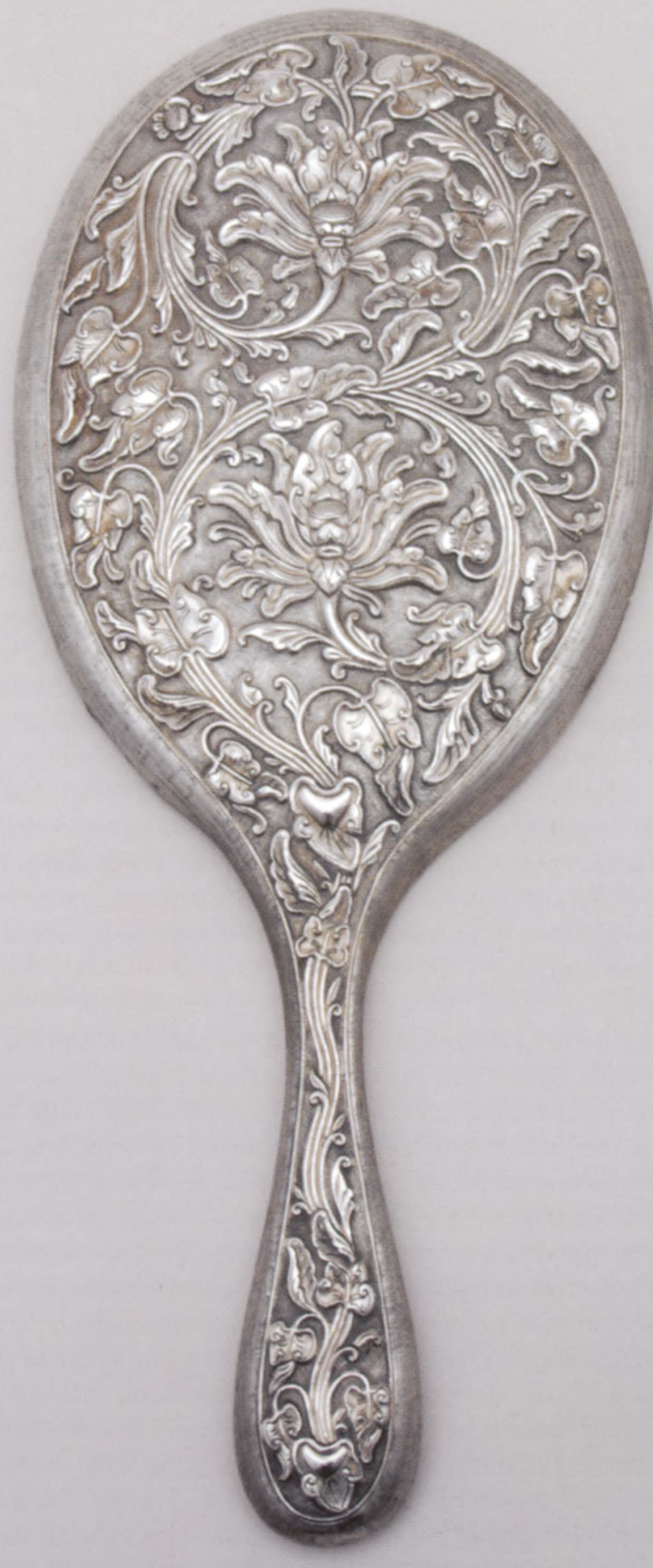


verarmde Javaanse adel liepen sinds het einde van de $19^{\mathrm{e}}$ eeuw steeds verder terug en de edelsmeden kregen geen aansluiting op de Europese markt in Nederlands-Indië. Kal geeft jammer genoeg geen expliciete redenen waarom

Afbeelding 2 Handspiegel, I. $32,2 \mathrm{~cm}$, 1930-1932, collectie Van Gesseler Verschuir

zij geen positie konden veroveren op die markt, maar het ligt voor de hand dat de benodigde tussenkanalen tussen zilversmid en (Europese) klant ontbraken.

De schrijfster merkt terecht op dat het merkwaardig is dat men het destijds geen probleem vond om een nieuwe ornamentiek te ontwikkelen voor het zilver, terwijl men tegelijkertijd neerkeek op de batikontwerpen (bijvoorbeeld de Batik Belanda) die afweken van de traditionele batikpatronen. Er werd van alles aan gedaan om de traditionele batiknijverheid levend te houden. Kal geeft geen verklaring voor het uiteenlopen van de visies op zilver en batik, maar deze ligt waarschijnlijk in de geringe waarde die de Nederlanders aan het traditionele zilver hechtten. Het batikken werd op grote waarde geschat, maar het traditionele Indonesische zilver werd als een gedegenereerde vorm van nijverheid beschouwd.

Over sommige constateringen van Kal lijkt het laatste woord nog niet gezegd. Zo uit zij in hoofdstuk twee haar verbazing over het gebruik van hindoeïstische motieven door de zilversmeden uit Kotagede, terwijl zij moslim waren en de islamitische beweging Muhammediyah (een beweging die terug wilde naar de werkelijke islam gebaseerd op de Al-Quran) hier haar basis had. Deze beweging is weliswaar te karakteriseren als orthodox of conservatief, maar het proces van islamisering van Java - dat overigens nog steeds gaande is vond geleidelijk plaats en begon juist níet bij de groep van handelaren en ambachtslieden. Het is daarom niet verbazingwekkend dat zilversmeden geen problemen hadden met deze oude motieven. Integendeel, het waren motieven uit de oude glorietijden van Java en gecombineerd met het opkomende nationalisme in Indonesië is het niet verwonderlijk dat de edelsmeden deze motieven ook na de onafhankelijkheid gebruikten.

Het is - tot slot - de vraag of de grote aandacht voor Van Gesseler Verschuir volledig op zijn plaats is. Zij richtte in 1932 een stichting op ter bevordering van de Javaanse nijverheid. Dit deed zij met onder andere R.P. Warindio die de leiding overnam nadat Verschuir al in datzelfde jaar uit Yogyakarta vertrok. Deze Indonesiër heeft de stichting tot 1950 geleid en moet daarom ook een grote invloed hebben gehad op de ontwikkeling van het zilver na 1932. Aan Warindio is echter maar één pagina tekst gewijd. Dat is erg jammer, omdat juist de rol die de Indonesiërs zelf gespeeld hebben nu sterk onderbelicht blijft. Verdere studie naar de ontwikkeling van het Yogya-zilver kan dus nog veel nieuws opleveren. Niet alleen in historisch opzicht, maar ook in kunsthistorisch opzicht. Het doosje (catalogusnummer 7) en de handspiegel (catalogusnummer 46) getuigen van het talent van edelsmeden die de oude motieven niet domweg kopieerden, maar de voorwerpen tot een elegant en vloeiend geheel wisten te smeden. Het vergelijken van zilveren voorwerpen op kwaliteit en artisticiteit kan in de toekomst het Yogya-zilver die erkenning geven die het verdient.

- P.W.H. Kal

Yogya Silver, Renewal of Javanese Handicraft

KIT publishers, Amsterdam, 2005

159 pagina's, zwart-wit illustraties 